\title{
An ELISA technique for rapid diagnosis of vibriosis in sea bass Dicentrarchus labrax
}

\author{
B. Romestand ${ }^{1}$, A. Dragesco ${ }^{1}$, G. Breuil ${ }^{2}$, F. Coste $^{1}$, G. Bouix ${ }^{1}$ \\ ${ }^{1}$ Laboratoire de Parasitologie et Immunologie, Case 096, Université Montpellier II Sciences et Techniques du Languedoc, \\ Place Eugène Bataillon, F-34095 Montpellier Cedex 05, France
}

${ }^{2}$ Station IFREMER, GIE Recherche Aquacole, Equipe de Pathologie, Chemin de Maguelone, F-34250 Palavas-les-Flots, France

\begin{abstract}
Three batches of rabbits were immunized against 2 strains of Vibrio anguillarum (Va V 62 and $V a V$ 408), which cause vibriosis in sea bass Dicentrarchus labrax (L. 1758) Serranidae. Homologous and heterologous reactions were obtained against these Vibrio strains and other bacteria using an improved indirect ELISA technique. Antibody and antigen titrations revealed high immunogenecity (high antibody titers for the antisera) of the 2 Vibrio strains. They correspond to serotype I and show close affinity. The specificity and sensitivity of 1 selected antiserum were tested on brain extracts from healthy sea bass and those infected artificially with $V$. anguillarum serotypes I and III. Preliminary results confirm the reliability of the technique and warrant its use for improving disease diagnosis.
\end{abstract}

\section{INTRODUCTION}

Vibriosis is one of the main causes of high mortality in farmed populations of sea bass Dicentrarchus labrax (L. 1758). In acute cases, the fish die of hemorrhagic septicemia and the mortality rate often exceeds $50 \%$ in farmed populations, particularly juvenile fish (Roberts 1975, Breuil \& Haffner 1989). In chronic cases, integument lesions of variable intensity on the body surface are accompanied by haemorrhaging in the abdominal cavity and by hemolytic anemia. Early diagnosis of the disease would ensure rapid treatment or elimination of infected individuals to prevent its spread.

At present, the only diagnostic method, apart from histopathological examination, is the identification of bacterial cells collected from integument fragments. The cells are seeded in an identification gallery and subjected to an agglutination test (Skoge Jonsen 1977. Simonson \& Siebeling 1988). However the first phase of this technique is too long and the test is not adequately sensitive to provide conclusive results.

Meanwhile, certain indirect ELISA techniques have produced satisfactory results for detecting Vibrio parahaemolyticus (Honda et al. 1985, 1989) and V. salmonicida (Espelid et al. 1988).

The objective of this study was to characterize the rabbit antisera produced for the ELISA tests according to their titer and specificity, and to assess the reliability of the indirect ELISA technique for detecting local Vibrio strains in farmed fish.

\section{MATERIALS AND METHODS}

Bacterial strains. Two Vibrio anguillarum strains corresponding to serotype I were used to obtain rabbit antisera. Strain V 62 (Va V 62), API E code 3247524 (Breuil \& Haffner 1989), was isolated from Mediterranean sea bass and strain $V 408$ ( $V a$ V 408), API 20E code 3247527 (Baudin-Laurencin 1981), from trout Salmo gairdneri Richardson. Both strains are highly pathogenic and cause septicemia in their respective hosts.

The specificity of the antisera produced against these 2 strains was studied by reacting them with other bacterial strains: Vibrio anguillarum, API 20E code 3247527, serotype III (Va V III); V. harveyi, V 605, API 20E code 4144527 (Vh V 605); V. parahaemolyticus, API 20E code 4146125 (Vp); and Pasteurella pisciscida, API 20E code 2004004 (Pp). These strains were supplied by the Institut Français de Recherche pour l'Exploitation de la Mer (IFREMER), France. 
All the bacterial cells used for immunization and corresponding ELISA tests were isolated from infected fish. They were cultured on marine agar (Difco) and incubated at $25^{\circ} \mathrm{C}$ for $24 \mathrm{~h}$. Their biochemical properties were identified using API $20 \mathrm{E}$ galleries. Cells were harvested after centrifugation, suspended in physiological saline at a concentration of $10^{9}$ cells $\mathrm{ml}^{-1}$, and heat-inactivated $\left(2 \mathrm{~h}\right.$ at $\left.18^{\circ} \mathrm{C}\right)$. Reserve antigen suspensions were maintained in buffers at $4^{\circ} \mathrm{C}$. Concentration rates of the bacterial suspensions were determined by colony forming unit (CFU) counts on bacteria cultured for $24 \mathrm{~h}$ on agarose.

Preparation of antisera. New Zealand female rabbits were inoculated with the 2 inactivated bacterial extracts ( $\mathrm{Va} V 62$ and Va V 408) according to the following proceciure:

- 1 intradermal injection containing $10^{9}$ cells $\mathrm{ml}^{-1}$ in Freund's incomplete adjuvant at $2 \mathrm{ml}$ per rabbit;

- 30 d later, a subcutaneous booster containing $2 \times 10^{9}$ cells $\mathrm{ml}^{-1}$ in Freund's incomplete adjuvant at $2 \mathrm{ml}$ per rabbit;

- 15 d later, a final booster identical to the preceding one

The 5 rabbits used for immunization were divided into 3 batches: Batch 1: $A, 1$ rabbit immunized against $\mathrm{Va} V$ 62; Batch 2: B, B', 2 rabbits immunized against Va $V$ 408, Batch 3: C, C', 2 rabbits immunized against a mix of Va V 62 and Va V 408. 1 non-immunized rabbit, $R_{0} S$, served as the control.

The rabbits were bled $15 \mathrm{~d}$ after the final booster. Serum was separated by centrifugation after coagulation. It was then aliquoted and stocked at $-80^{\circ} \mathrm{C}$.

Artificial infection, challenges. The sea bass (30 g) were reared at IFREMER in 5001 tanks in which the water was maintained at $20^{\circ} \mathrm{C}$ and $35 \%$ salinity and renewed at the rate of $500 \mathrm{l} \mathrm{h}^{-1}$

Two strains belonging to different serotypes were used for inoculation: Va V 62 from serotype I and Va V III from serotype III. For each strain, 36 fish were artificially infected by intraperitoneal injection of $0.1 \mathrm{ml}$ of bacterial suspension $\left(1 \times 10^{7}\right.$ cells $\mathrm{ml}^{-1}$ for $\mathrm{Va} V 62$ and $2 \times 10^{7}$ cells $\mathrm{ml}^{-1}$ for Va V III). The controls were injected with $0.1 \mathrm{ml}$ of physiological saline.

After $10 \mathrm{~d}$, samples of brain and kidney tissue from dead fish were checked for the presence of Vibriospp., using standard techniques. Agglutination tests were carried out on samples cultured on marine agar (Difco) and seeded on API 20E identification galleries.

Healthy and infected brain extracts were used for assessing the indirect ELISA technique. In all cases healthy fish were used as controls.

Indirect ELISA technique. Certain modifications were made to the ELISA technique to obtain reliable results. These included fixing agents (different concentrations of poly L-lysine), microtitration plates
(Greiner, Nunc, with normal or hyperabsorption), and saturation buffers (BSA, Régilait, casein, etc.).

Titration of antisera. The procedure used for antiserum titration was as follows:

(1) Wells of a flat-bottomed Nunc-ELISA plate were coated with $50 \mu \mathrm{l}$ of a bacterial suspension at the rate of $10^{7}$ cells $\mathrm{ml}^{-1}$ in phosphate-buffered saline (PBS), $\mathrm{pH}$ 7.2. The plate was then incubated at $60^{\circ} \mathrm{C}$ for $3 \mathrm{~h}$ (patented modification, Guillet et al. 1983).

(2) The plate was washed 3 times by adding $200 \mu \mathrm{l}$ of PBS to each well. The wells were emptied by suction, using an automatic plate washer (Nunc). Any excess solution after the last wash was removed by quickly overturning the plate on blotting paper.

(3) Saturation was obtained by adding $300 \mu \mathrm{l}$ of $0.3 \%$ BSA/PBS ( $w / v)$ in each well. The plate was covered and incubated at $37^{\circ} \mathrm{C}$ for $1 \mathrm{~h}$. During incubation, dilutions of each antiserum sample were prepared in $0.2 \%$ BSA/PBS $(w / v)$. The dilutions generally ranged between $1: 10^{3}$ and $1: 10^{6}(\mathrm{v} / \mathrm{v})$. The nonspecific solution (control) was prepared using $0.2 \% \mathrm{BSA} / \mathrm{PBS}$ (w/v).

(4) The saturation solution was removed by suction and the plate was dried.

(5) Each well was washed 3 times with PBS (300 $\mu 1$ the first time and $200 \mu$ l the next 2 times). The plate was then dried.

(6) Fifty $\mu$ l of one of the following were deposited in each well:

(a) antiserum from immunized rabbits at different dilutions in $0.2 \%$ BSA/PBS $(w / v)$ ranging between $1: 10^{3}$ and $1: 10^{6}$;

(b) serum from the nonimmunized rabbit at the same dilutions as in (a);

(c) buffer solution of nonspecific $0.2 \%$ BSA/PBS $(\mathrm{w} / \mathrm{v})$

The plate was incubated for $2 \mathrm{~h}$ at room temperature $\left(20 \pm 2^{\circ} \mathrm{C}\right)$.

(7) The solution was removed, each well was washed 3 times with $200 \mu \mathrm{l}$ of PBS, and the plate was dried.

(8) Fifty $\mu$ l of conjugate made up of anti-rabbit antibody diluted to $1: 4000(\mathrm{v} / \mathrm{v})$ in $0.2 \% \mathrm{BSA} / \mathrm{PBS}(\mathrm{w} / \mathrm{v})$ was added to each well. The plate was covered and incubated at $37^{\circ} \mathrm{C}$ for $1 \mathrm{~h}$.

(9) The solution was removed by suction. The plate was washed 3 times with $200 \mu$ l of PBS and dried.

(10) Fifty $\mu$ l of chromogenic substrate (orthophenylenediamine: R8 Rapid Elavia reagent and R9 Monolisa AgHBS, Eria Diagnostic Pasteur), prepared just before use, was added to each well. The plate was incubated for $10 \mathrm{~min}$ in the dark and at room temperature.

(11) The reaction was stopped, without washing, by adding $25 \mu \mathrm{l}$ of $\mathrm{H}_{2} \mathrm{SO}_{4} 4 \mathrm{~N}$ to the solution

(12) Optical density was measured immediately at $492 \mathrm{~nm}$ by means of a plate reader (TitertekMultiskan). 
Titration of antigens. The same procedure was used for antigen titration except for Steps 1 and 6; they were replaced by:

(1') Wells of a flat-bottomed Nunc ELISA plate were coated with $50 \mu \mathrm{l}$ of bacterial suspensions at different concentrations $\left(10^{9} \text { to } 10^{3} \text { cells } \mathrm{ml}^{-1} \text { in } \mathrm{PBS}\right)_{i}$ they were incubated and dried at $60^{\circ} \mathrm{C}$ for $3 \mathrm{~h}$

(6') Fifty $\mu$ l of one of the following were deposited in each well

(a) antiserum from immunized rabbits, at constant dilution $\left(1: 2 \times 10^{4}, \mathrm{v} / \mathrm{v}\right)$ in $0.2 \% \mathrm{BSA} / \mathrm{PBS}(\mathrm{w} / \mathrm{v})$;

(b) serum from the nonimmunized rabbit at the same dilution as in (a);

(c) buffer solution of nonspecific $0.2 \% \mathrm{BSA} / \mathrm{PBS}$ $(\mathrm{w} / \mathrm{v})$

The plate was incubated for $2 \mathrm{~h}$ at room temperature $\left(20 \pm 2{ }^{\circ} \mathrm{C}\right)$

Assessment of the ELISA technique. The ELISA technique was tested by checking its ability to detect Vibrio anguillarum antigens - serotypes I (Va V 62) and III (Va V III) - in brain extracts of infected fish. The indirect ELISA technique used for this purpose was similar to that for antiserum titration except for Steps 1 and 6 , which were replaced by:

(1") Wells of a flat-bottomed Nunc ELISA plate were coated with $50 \mu \mathrm{l}$ of infected (or healthy) brain extracts. These were previously homogenized (Dounce) for 2 min in $600 \mu \mathrm{l}$ of sterile PBS and then diluted at different concentrations $(1: 10,1: 30,1: 150,1: 1500,1: 15000)$ in sterile PBS. The plate was then incubated at $60^{\circ} \mathrm{C}$ for $3 \mathrm{~h}$

(6") Fifty $\mu$ l of one of the following were deposited in each well:

(a) antiserum from rabbits immunized against $\mathrm{Va} V$ 62 , at constant dilution $\left(1: 10^{4}, \mathrm{v} / \mathrm{v}\right)$ in $0.2 \% \mathrm{BSA} / \mathrm{PBS}$ $(\mathrm{w} / \mathrm{v})$;

(b) serum from the nonimmunized rabbit at the same dilution as in (a);

(c) buffer solution of nonspecific $0.2 \%$ BSA/PBS $(\mathrm{w} / \mathrm{v})$

The plate was incubated for $2 \mathrm{~h}$ at room temperature $\left(20 \pm 2^{\circ} \mathrm{C}\right)$.

\section{RESULTS}

\section{Antiserum titration: homologous and heterologous reactions \\ (Table 1, Fig. 1)}

In this test, the antibody concentration varied whereas that of the antigen was constant $\left(1 \times 10^{7}\right.$ cells $\mathrm{ml}^{-1}$ or $2 \times 10^{6}$ cells per well). Results showed that:

- Optic density (OD) was low (0.15) owing to background interference (nonspecific buffer).

- Regardless of the antigen, serum from the nonimmunized rabbit $\left(\mathrm{R}_{0} \mathrm{~S}\right)$ at both dilutions $\left(1: 10^{3}\right.$ and $1: 10^{4}$, $v / v)$ gave very low OD: $<0.3$ at $1: 10^{3}$ and close to 0 at $1: 10^{4}$.

- The antibody titer ${ }^{*}$ of antisera from immunized rabbits was higher for homologous reactions than for heterologous reactions. For example, the antiserum produced by rabbit A against Va V 62 gave a high titer $\left(2 \times 10^{5}\right.$ and $1.6 \times 10^{5}$ respectively) when reacted with strains $V a V 62$ and Va V 408, which belong to the same serotype. In comparison, antibody titers obtained in the presence of other antigens were: $7 \times 10^{4}$ with Vh V $605,2.3 \times 10^{4}$ with Va VIII and $1.2 \times 10^{3}$ with $\mathrm{Pp}$. The same phenomenon was observed for homologous and heterologous reactions of antisera from $B, B^{\prime}, C$, and $C^{\prime}$ rabbits.

- As expected, the Va V 62 and Va V 408 strains, which belong to the same serotype, showed greater affinity between themselves than with Va V III or Vh V 605

- In one case, antisera from rabbits $C$ and $C^{\prime}$ immunized against both Va V 62 and Va V 408 appeared to produce a slightly stronger reaction to the 2 antigens presented separately. The antiserum $C$ titer $\left(3 \times 10^{5}\right)$ is higher than that of antisera $A, B$, and $B^{\prime}$

- The antibody titer of an antiserum was defined as being equal to the dilution at which its OD was 3 times the background interference (Mourton 1991)

Table 1. Antibody titers (inverse value of dilution) of antisera from rabbits immunized against 2 Vibrio anguillarum strains, as determined by indirect ELISA. ND: not determined. Results of homologous reactions are in bold

\begin{tabular}{|lrrrrrr|}
\hline Antigen & Antiserum A & Antiserum B & Antiserum B' & Antiserum C & Antiserum C' & $\begin{array}{c}\text { Serum } \\
R_{0} \text { S (control) }\end{array}$ \\
\hline Va V 62 & $2 \times \mathbf{1 0}^{\mathbf{5}}$ & $2 \times 10^{5}$ & $8 \times 10^{4}$ & $\mathbf{3} \times \mathbf{1 0 ^ { 5 }}$ & $\mathbf{1 . 5} \times \mathbf{1 0 ^ { 5 }}$ & 0 \\
Va V 408 & $1.6 \times 10^{5}$ & $\mathbf{1 . 7} \times \mathbf{1 0 ^ { 5 }}$ & $\mathbf{8} \times \mathbf{1 0 ^ { \mathbf { 4 } }}$ & ND & $\mathbf{8} \times \mathbf{1 0 ^ { \mathbf { 4 } }}$ & 0 \\
Vh V 605 & $7 \times 10^{4}$ & $1.6 \times 10^{4}$ & $1.6 \times 10^{4}$ & $2.8 \times 10^{4}$ & $2.4 \times 10^{4}$ & 0 \\
Va V III & $2.3 \times 10^{4}$ & $9.5 \times 10^{3}$ & ND & ND & ND & 0 \\
Vp & $2.8 \times 10^{3}$ & $1.4 \times 10^{3}$ & ND & ND & $3.5 \times 10^{3}$ & 0 \\
Pp & $1.2 \times 10^{3}$ & $<1 \times 10^{3}$ & ND & ND & $2.2 \times 10^{3}$ & 0 \\
\hline
\end{tabular}



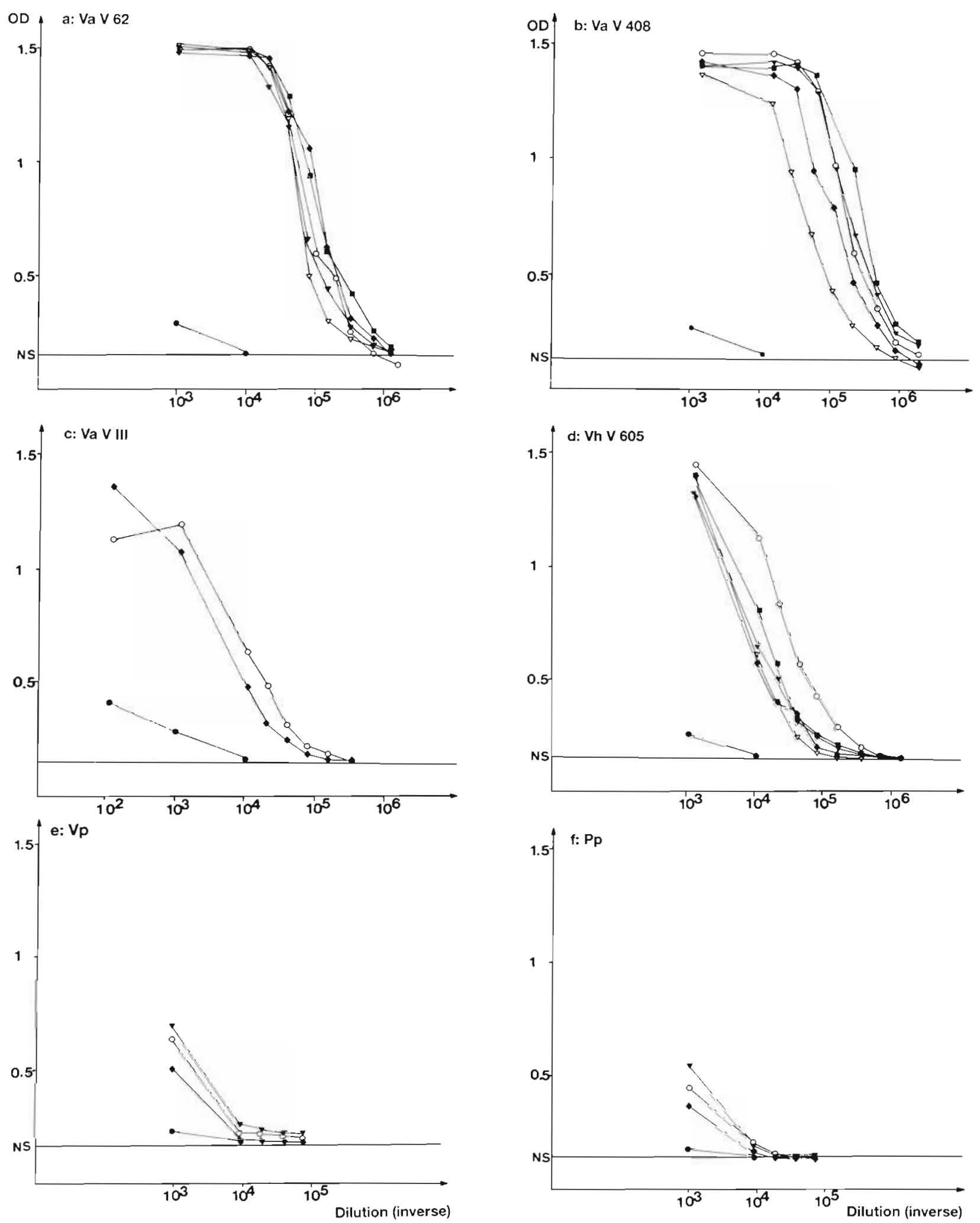

Fig. 1. Antiserum titers as determined by indirect ELISA. Antigens $\left(10^{7}\right.$ cells $\mathrm{ml}^{-1}$ ): (a) $\mathrm{Va} V 62$ and (b) Va V 408 : Vibrio anguillarum serotype I; (c) Va V III: V. anguillarum serotype III; (d) Vh V 605: V. harveyi (e) Vp: V. parahaemolyticus; (f) Pp: Pasteurella

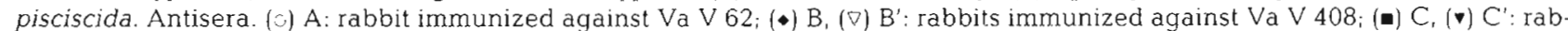
bits immunized against $\mathrm{Va} V 62$ and $\mathrm{Va} V$ 408; $(\bullet) \mathrm{R}_{0} \mathrm{~S}$ : serum of nonimmunized rabbit (control) $\bullet$ OD: optical density; NS: nonspecific 


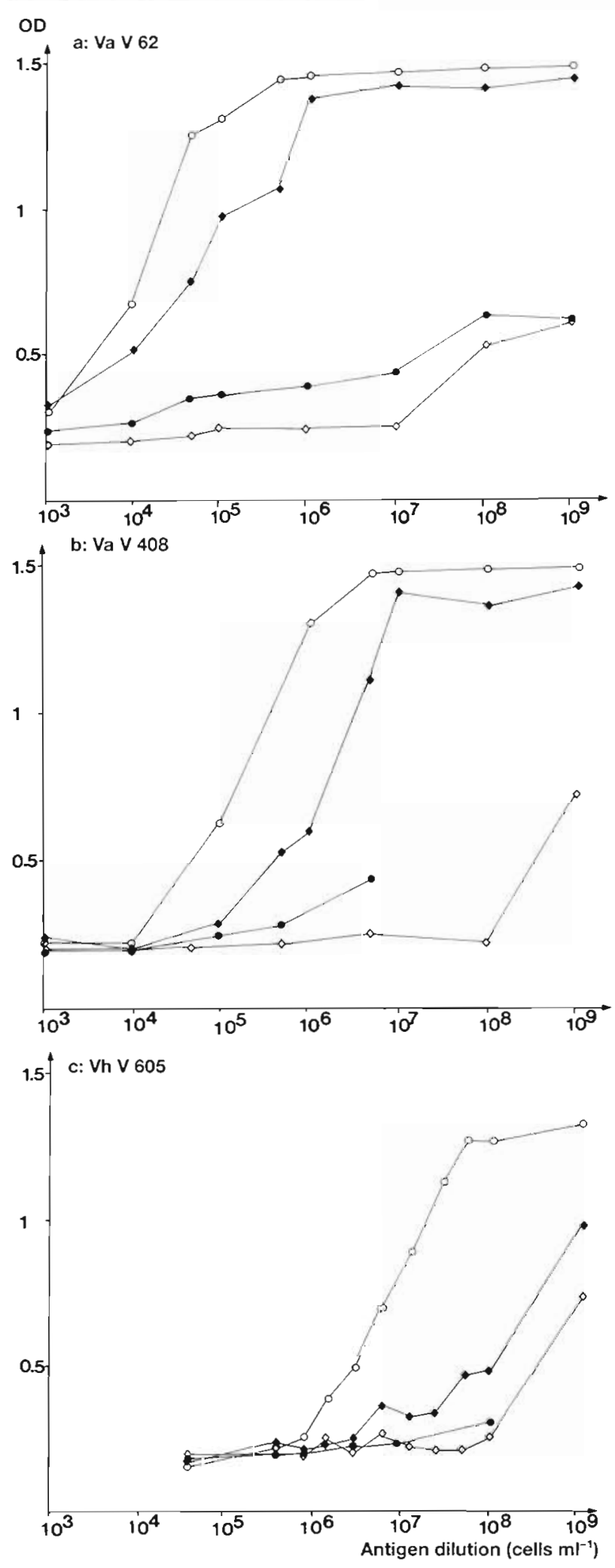

Fig. 2. Bacterial antigen titers as determined by indirect ELISA. Antigens: (a) Va V 62: Vibrio anguillarum serotype I; (b) Va V 408: V. anguillarum serotype I; (c) Vh V 605: V. harveyi. Antisera (constant dilution $1: 2 \times 10^{4}, \mathrm{v} / \mathrm{v}$ ): (0) A: rabbit immunized against Va V 62; $(\bullet)$ B; rabbit immunized against $\mathrm{Va} \mathrm{V} 408 ;(\bullet) \mathrm{R}_{0} \mathrm{~S}$ : serum of non-immunized rabbit (control) (o) non-specific; OD: optical density
Table 2. Antigen titration tests. No. of bacterial cells per ml required to obtain optical density 3 times the background interference, using different antisera (constant dilution, $1: 2 \times$

$10^{4}$ ). Results of homologous reactions are in bold

\begin{tabular}{|c|c|c|c|}
\hline \multirow[t]{2}{*}{ Rabbit antisera } & Va V 62 & Va V 408 & Vh V 605 \\
\hline & \multicolumn{3}{|c|}{ (bacterial cells $\mathrm{ml}^{-1}$ ) } \\
\hline A & $3 \times 10^{4}$ & $7 \times 10^{5}$ & $0.15 \times 10^{7}$ \\
\hline B & $1 \times 10^{5}$ & $3.5 \times 10^{6}$ & $1 \times 10^{9}$ \\
\hline
\end{tabular}

$\left(2 \times 10^{5}, 2 \times 10^{5}, 8 \times 10^{4}\right.$ respectively) when reacted with Va V 62 .

- The antisera were absorbed by corresponding heterologous bacterial strains to increase antiserum specificity, but this also reduced their sensitivity.

\section{Antigen titration \\ (Table 2, Fig. 2)}

In this indirect ELISA test antisera from $A$ and $B$ rabbits were used at a given constant dilution (generally $1: 2 \times 10^{4}$, corresponding to an $\mathrm{OD}$ of 1 ) on plates coated with variable concentrations of $\mathrm{Va} \mathrm{V} 62$, Va $\mathrm{V}$ 408 , and $V h V 605$ (dilutions from $10^{9}$ to $10^{3}$ cells $\mathrm{ml}^{-1}$ ).

The results obtained with the 3 strains and 2 antisera confirmed earlier results:

- The number of bacterial cells per ml required to obtain the predetermined OD level ( 3 times the background interference) was lower for homologous reactions compared with heterologous reactions. Antiserum A was generally more sensitive than antiserum $B$.

- Strains Va V 62 and Va V 408, which belong to the same serotype, appeared to have a larger number of common antigen determinants between themselves than with Vh V 605.

\section{Assessment of the indirect ELISA technique using brain extracts of artificially infected fish}

(Fig. 3)

The final stage was devoted to an assessment of the indirect ELISA technique. The objective was to determine whether the technique developed by us could be used to detect pathogenic Vibrio anguillarum in artificially infected sea bass.

The mortality rate $10 \mathrm{~d}$ after artificial infection was $70 \%$ for fish infected with Va V 62 and $74 \%$ for fish infected with Va V III. It was $0 \%$ in healthy controls.

All the dead fish carried bacterial cells; these were isolated from brain and kidney tissue and identified 


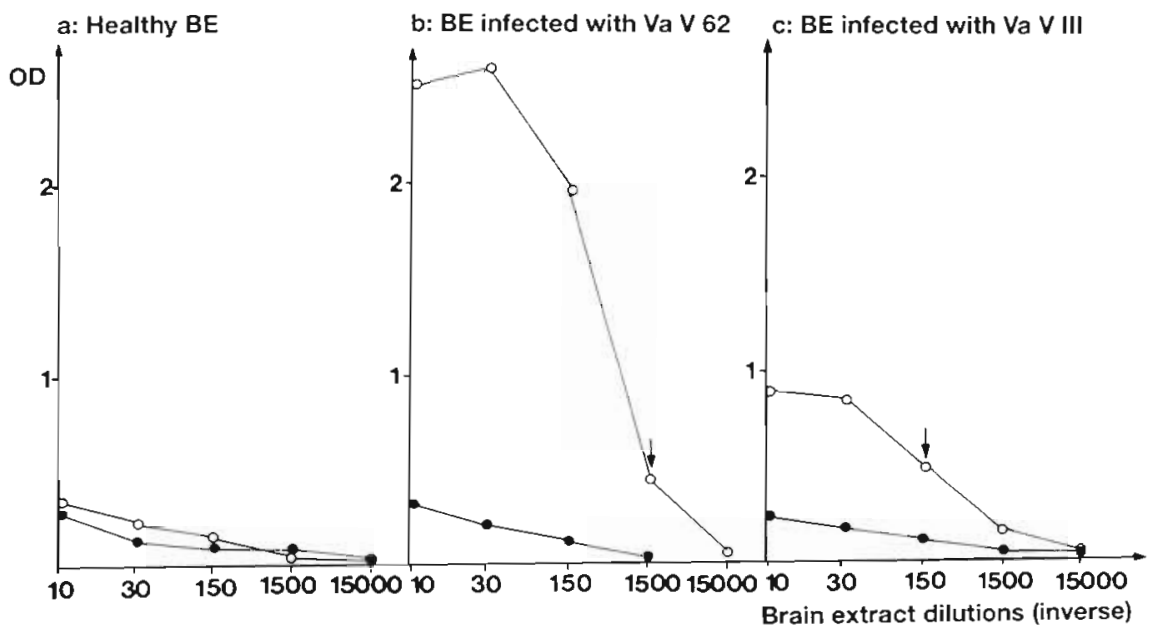

Fig. 3. Reaction of (a) healthy brain extracts (BE), and those infected with (b) $\mathrm{Va} V 62$ and (c) Va V III to (o) antiserum of rabbit A immunized against Va V 62 (dilution 1:104,

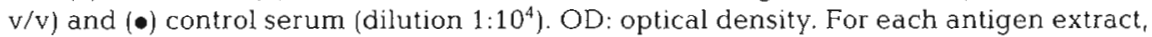
background interference was subtracted from the OD value of each antiserum. See text for explanation of arrows

using standard techniques. No bacterial cells were found in brain and kidney tissue of the healthy controls.

Using the improved indirect ELISA technique, we studied the reactions of antiserum A (antibodies against $\mathrm{Va} V$ 62) and serum from the nonimmunized rabbit $\left(R_{0} S\right)$ to healthy brain extracts and those from fish infected with Va V 62 and Va V III. Antiserum A and serum $R_{0} S$ were used at a constant dilution of $1: 10^{4}$, whereas the brain extracts were deposited at different dilutions in microtitration plate wells. The results showed that:

- Regardless of the type of brain extract (healthy, infected by $\mathrm{Va} V 62$ or Va V III) and its dilution, $\mathrm{R}_{0} \mathrm{~S}$ serum gave no significant $O D$.

- Antiserum A containing antibodies against Va V 62 did not detect any challenge in healthy brain extracts (Fig. 3a) but gave a significant OD in reaction to Va V 62-infected brain extracts for dilutions equal to or less than 1:1500 (Fig. 3b, arrow). Antiserum $A$ weakly recognized Va V III in brain extracts infected with the corresponding antigen, but only at dilutions equal to or less than 1:150 (Fig. 3c, arrow).

The results confirmed the high sensitivity of the antiserum to Va V 62 both in vitro (buffered antigen suspension) and in vivo (infected brain extract). The reactions are specific to the bacterium because $O D$ was 0 with healthy brain extract. A slight crossed reaction of the antiserum with Va V III suggests that the strain presents certain antigenic affinities with $\mathrm{Va} V 62$.

These preliminary results confirm the validity of the indirect ELISA technique for detecting Vibrio anguillarum in infected fish brain extracts.

\section{DISCUSSION}

This study complements research already accomplished on various fish vibrioses. Earlier work on cold water vibriosis (Hitra disease) caused by Vibrio salmonicida, which was based on the use of polyclonal (Holm \& Jørgensen 1987) and monoclonal (Espelid et al. 1988) antibodies, led to the development of taxonomic classification and diagnoses of the initial stages of the disease.

In the present study on vibriosis in farmed sea bass, high titers were obtained for the different rabbit antisera: between $8 \times 10^{4}$ and $3 \times 10^{5}$ in homologous reactions for an antigen concentration of $10^{7}$ cells $\mathrm{ml}^{-1}$.

This clearly demonstrates the high immunogenicity of the 2 inactivated Vibrio anguillarum strains. It also confirms results obtained by other authors for these strains using agglutination tests (BaudinLaurencin 1981, Sørensen \& Larsen 1986, Breuil \& Haffner 1989).

There is a definite antigenic affinity between the selected strains Va V 62 and Va V 408, which belong to serotype I. They differ from certain other Vibrio strains and other genera of bacteria with which they were compared in this study. The extreme sensitivity of the indirect ELISA technique enabled us to identify cross reactions between the different antisera and certain other Vibrio strains, particularly Va V III which is also pathogenic in farmed sea bass. These cross reactions are usually not clearly perceptible in agglutination tests. We concluded that the strains selected from different serotypes may present certain antigenic affinities.

To increase the specificity of the test antisera we undertook absorption reactions of each antiserum by corresponding heterologous bacterial strains. Although their specificity increased, their sensitivity was reduced.

Agreement between the antiserum and antigen titrations validates the use of Va V 62 antisera for detecting Vibrio spp. in infected sea bass tissue using a selected polyclonal rabbit antiserum.

Artificial infection of fish with other bacterial strains (Vibrio ordali, Pasteurella pisciscida) using different techniques are planned. They will be useful for developing field-usable diagnosis kits to detect various pathogens of sea bass. 
Acknowledgements. We thank M. J. F. Pepin of Laboratoire MEREA, IFREMER, France, for his assistance in the bacterial studies (identification and inactivation of bacterial cells, preparation of titrated bacterial suspensions, artificial infection of farmed fish)

\section{LITERATURE CITED}

Baudin-Laurencin, F. (1981). Fish Vibrio strains antisera in France. Devl. Biol. 49: 257-259

Breuil, G., Haffner, P. (1989). A field report on Vibrio disease of sea bass. Dicentrarchus labrax, in the South of France. In: Advances in tropical aquaculture, Tahiti $20 \mathrm{Feb}-4 \mathrm{Mar}$ 1989. Aquacop IFREMER Actes de Colloque 9: 161-169

Espelid, S., Holm, K. O., Hjelmeland, K., Jorgensen, T. (1988). Monoclonal antibodies against Vibrio salmonicida: the causative agent of coldwater vibriosis ('Hitra disease') in Atlantic salmon, Salmo salar L. J. Fish Dis. 11: 207-214

Guillet, J. G., Hoebeke, J., Tram, C., Strosberg, A. D. (1983). Anticorps monoclonaux anti-Legionella, procédé d'obtention et application au diagnostic des pneumonies. Patent No. 8302789. Paris

Holm, K. O., Jørgensen, T (1987). A successful vaccination of Atlantic salmon (Salmo salar L.) against 'Hitra disease', a cold water vibriosis. J. Fish Dis. 10: 85-90

Responsible Subject Editor: W. Ahne, Munich, Germany
Honda, T., Ni, Y., Yoh, M., Miwatani, T. (1989). Production of monoclonal antibodies against thermostable direct lysin of Vibrio parahaemolyticus and application of the antibodies for enzyme-linked immunosorbent assay. Med. Microbiol. Immunol. 178: 245-253

Honda, T., Yoh, M., Kongmuang, U., Miwatani, T (1985) Enzyme-linked immunosorbent assays for detection of thermostable direct hemolysin of Vibrio parahaemolyticus. J. clin. Microbiol. 22: 383-386

Mourton, C. (1991). Immunotechnologies appliquées à la détection du virus de la septicémie hémorragique virale. Potentiel diagnostique des anticorps monoclonaux spécifiques de la glycoprotéine d'enveloppe ou de la nucléocapside. Doctorate thesis, Université Montpellier I

Roberts, R. J. (1975). Pathologie du poisson. Maloine Editeur, Paris

Simonson, J. G., Siebeling, R. J. (1988). Coagglutination of Vibrio cholerae, Vibrio mimicus and Vibrio vulnificus with antiflagellar monoclonal antibody. J. clin. Microbiol. 26: 1962-1966

Skøge Jonsen G., (1977). Immunological studies on Vibrio anguillarum. Aquaculture 10: 221-230

Sørensen, V. B. S., Larsen, J. L. (1986). Serotyping of Vibrio anguillarum. A.ppl. environ. Microbiol. 51: 593-597

Manuscript first received: September 24, 1991

Revised version accepted: November 10,1992 